of "Alexander Stephen \& Sons". The two vessels are about the same size, but the Bear was a little narrower and had not Discovery's stern : the former showed perhaps rather better behaviour in dirty weather.

It is almost impossible to believe that there is no more scientific work for a ship built to withstand the ice, and it is therefore the more important that there should be preserved records, as minute as possible, dealing with the construction and performance of such vessels. If thirty-three years ago Scott could write that "it is all passing away", there is much more reason for apprehension now. Mr. Wead has written a sound book in a perfectly straightforward manner and is to be complimented on avoiding the dramatic. It is rather a pity that in the brief outline of Alaskan history he omits the name of the indomitable Baranov.

J. E. H.

\section{The Scenery of England and Wales}

By Prof. A. E. Trueman. Pp. 351. (London: Victor Gollancz, Ltd., 1938.) 7s. 6d. net.

$\mathrm{N}$ his opening sentence, the author points out that 1 "In England and Wales we are singularly placed to appreciate the relationship of scenery and structure, for few other parts of the earth's surface show in a similar small area so great a diversity of rock types and of landscape features". In this attractive little book, addressed to walkers and motorists, as well as to students, an easily intelligible and pleasantly written attempt to stimulate that appreciation has been made.

Although, as a geologist, Prof. Trueman sees scenery from an anatomical point of view, as the external expression of internal structure, he does not omit to mention the softening influences of "waters blown by changing winds to laughter", or to exemplify the harmonious effects of native stone on the domestic architecture of the unspoilt countryside. Each chapter deals with one area or type of country, such as the Cotswold Stone Belt, the Pennine Moorlands, the Lake District, South Devon and Cornwall, and they are so arranged that the more complex regions come last.

The work concludes with "A Chronology of the Changing Scene" and a brief survey of the geological history of the varied landscapes and seascapes that have culminated in our present-day geography. In a future edition the very short appendix on maps and books might advantageously be amplified.

\section{Geology}

Landslides and Related Phenomena

a Study of Mass-Movements of Soil and Rock. By C. F. Stewart Sharpe. Pp. iv $+137+9$ plates. (New York : Columbia University Press ; London : Oxford University Press, 1938.) 15s. net.

IN this excellent and well-illustrated book the 1 author covers the whole field of his subject by treating the phenomena, not as isolated processes, but as stages in two continuous series, "in each of which there is every transition from moving masses of dry rock and soil at one extreme to masses of rock and soil abundantly impregnated with water or ice at the opposite end of the sequence". The movements themselves are distinguished as flow (continuous deformation) and slip (mass movement along a plane separating the moving mass from the stable ground), and each type is further subdivided in terms of rate of movement. The classification thus arrived at is by far the best yet proposed, and has the great advantage of clearly relating the co-operating processes and resulting forms to those of the recognized geomorphic cycles.

Though brief, the book has a well-selected bibliography and is thoroughly comprehensive. Despite its high price, it is an indispensable work of reference that no geologist can afford to ignore.

Geologisches Wörterbuch, Erklärung der geologischen Fachausdrücke :

für Geologen, Paläontologen, Mineralogen, Berg. ingenieure, Geographen, Bodenkundler, Studierende und alle Freunde der Geologie. Von Dr. Carl Chr. Beringer. Pp. vii + 126. (Stuttgart: Ferdinand Enke, 1937.) 5.60 gold marks.

$\mathrm{T}$ this German handbook of geological terms the definitions, descriptions and explanations are given briefly and in simple language. Where it has seemed desirable, illustrations are provided, and certain terms, such as erzlagerstätten, faltungsphase, formationskunde, orogenese, schichtung, are amplified by means of schemes of classification. In Germanspeaking countries, the book will be a useful guide to the "hard words and forbidding technicalities" of a subject which is much more attractive than its German nomenclature. In English-speaking countries, students of geology, geography and related subjects will find the book invaluable, whether they are learning to read scientific German or, at a higher level of ambition, attempting to cope with the growing flood of German contributions to geological literature. Clear explanations will here be found of many words for which hitherto they may have searched in vain.

\section{Mathematics}

The Principles of Mathematics

By Bertrand Russell. Second edition. Pp. xxxix +534 . (London: George Allen and Unwin, Ltd., 1937.) 18s. net.

A ANY thinkers have regretted Bertrand Russell's 1 desertion of the arid beauties of mathematical logic for the alluring dangers of practical ethics and sociology. This new edition of the "Principles of Mathematics" will be welcomed by them not only because it makes accessible to all a book which fetched eight guineas when a stray copy could still be found, but also for its preface which many might wish to consider as a 'return to mathematical logic'. This preface of ten pages shows, in fact, that Russell has never lost his interest in the subject. $\mathrm{He}$ tells us that he sees no reason as yet to modify his views on his fundamental thesis of the identity 